\title{
Encountering the 'Other' by Lifting the Iron Curtain: American Newspaper Editors' Global Campaigns for Bridges of Understanding, 1961-1970
}

\begin{abstract}
After World War II, American Society of Newspaper Editors members focused on sharing their journalistic ideals with Soviet journalists. Between 1961 and 1970 Soviet journalists travelled to the United States, ASNE members travelled to the Soviet Union to encourage greater free flows of information between both countries. This study provides insights into American editors' transnational activities and attempts to spread Western journalistic ideals during the Cold War. Drawing on archival records, this article examines what motivated American editors to participate in journalism exchanges with journalists in a communist country, how American editors presented the Soviet Union to American readers, and whether American editors suggested these exchanges could advance information flows between both nations. Analysis of extensive primary sources indicates American editors contrasted their freedoms with Soviet controls. Editors' diary entries, correspondence, and articles described Americans' advocacy for journalists to receive greater access to information, places, and people.
\end{abstract}

\section{Keywords}

ASNE, advocacy, journalism, freedom of information, Cold War

American journalists historically have advocated for press freedom within a distinctly free press system. After World War II, members of the American Society of Newspaper Editors (ASNE) extended their advocacy for free flows of information beyond the United States. They aimed to build awareness between different countries to prevent the rise of nationalism from occurring again. These efforts started in the mid-1940s and continued through the Cold War. After the end of World War II and during the allied political struggle, 'freedom of information' became the philosophy for a free and democratic world in which Americans asserted their influence on a global scale. ${ }^{1}$ 
American media historian Margaret Blanchard chronicled changes in the name and focus of the freedom of information movement during the mid-twentieth century. The campaign focus shifted to 'freedom of the press' ${ }^{2}$ then 'freedom of the American system of the press.' US newspaper editors and members of journalism professional organisations fought for international press freedom with and through discussions with members of the US government. American newspaper editors and the US Department of State attempted to spread American values beyond the United States. ${ }^{3}$

In 1962 and 1969 two ASNE groups travelled to the Soviet Union with hopes to improve US Department of State journalists' access to information in the USSR, and Soviet journalists travelled to the United States in 1961 and 1970. ${ }^{4}$ Although American newspapers paid for Americans' travels and editors went as representatives of ASNE, ${ }^{5}$ these exchanges were in line with the US Department of State's détente policy, the easing of political tensions, which characterised the late 1960s to 1970s. This study primarily examines American newspaper executives' perceptions of these exchanges, as they advocated for Americans to receive better access to news and information. Observing social and political differences between these countries, American editors contrasted the nations' cultures and press systems. Previously published scholarship has not focused on whether and how American editors engaged in transnational journalism campaigns as they envisioned spreading their free flow of information ideals to communist countries.

This study aims to highlight how US editors perceived Soviet journalism and press freedom during these exchanges. American editors involved in the exchanges recorded their experiences in memos, letters, speeches, diaries, and stories. Analysis of these archival documents has shown what inspired participation in these exchanges and what transpired during these exchanges. The analysis identified common themes among editors' perceptions of Soviet culture, politics, and journalism, particularly as they contrasted the editors' conceptions of a closed Soviet system with an open American system.

The theoretical framework for this research is grounded in the Four Theories of the Press, ${ }^{6}$ the Freedom of Information Campaign,${ }^{7}$ and the transnational journalism paradigm, ${ }^{8}$ which are explained later in the article. This study aims to contribute to transnational journalism research with insights on US journalists' efforts to improve access to information and spread American ideals for press freedom beyond US borders during a time when the role of journalism as a diplomatic 'soft power' became more pronounced. 


\section{The post-World War II freedom of information campaign}

Campaigning for freedom of information is a theme prevalent in American journalism history. ${ }^{9}$ Blanchard traced desires for freedom of information and free expression in modern America to the revolutionary character of the First Amendment. ${ }^{10}$ Journalism scholar Michael Schudson connected the citizen's right to know movement to a mid-twentieth century reform movement by politicians, watchdog journalists and social advocates. That movement for government transparency attempted to improve citizens' access to government-held information. ${ }^{11}$ The passage of the Freedom of Information Act (FOIA), signed into law in 1966, marked a turning point in the American public's right to access and review information from US government agencies. ${ }^{12}$

Political communication scholar Tim Cook described the news media as a political institution that shapes government policies worldwide. ${ }^{13}$ Editors became political actors, ${ }^{14}$ advocating for strategic objectives, which may also relate to the sociology and history of news production. ${ }^{15}$ Journalists have connected their advocacy for access to information to their professional duty to monitor and report on government actions. ${ }^{16}$ Through campaigns for freedom of information laws and greater government transparency, journalistic institutions aimed to improve access to government records in the United States during the Cold War era. ${ }^{17}$

Scholarship has described the right to know movement as journalists' reaction against a culture of secrecy, expanded government power, and bureaucratic control of information. ${ }^{18}$ Editors, influenced by social and political agendas, believed in the liberal democratic principle of press freedom and their responsibility to inform the public, thus they organised and initiated this right to know campaign between 1955 and 1966. ${ }^{19}$ Ronald Farrar, in 1971, emphasised the importance of historical media scholarship related to press responsibility and press freedom, yet little has been published about editors' efforts to improve accuracy of foreign reporting through their international advocacy for press freedom in the 1960s. ${ }^{20}$

After World War II American correspondent George Seldes criticised American press leaders' efforts to export their values and cultures. ${ }^{21}$ Seldes indicated the press failed to serve the people, as people did not know what was happening at the onset of the Cold War. Instead, the press followed their own agenda, allowing the public to become misinformed. ${ }^{22} \mathrm{~A}$ recent study even described American news' involvement in 'brainwashing' the public during the Cold War, as the onset of the Cold War created a sense of panic, with media inaccurately reporting on the geopolitical situation. ${ }^{23}$ 
Previously published media histories have mentioned American newspaper editors' advocacy for freedom of information in the United States and abroad during the post-World War years. ${ }^{24}$ This study expands on previous research, providing empirical analysis of ASNE members' archival records addressing Americans' efforts to encourage free flows of information and to share American ideals for press freedom.

\section{Cold War, propaganda and cultural soft power}

Both superpowers used propaganda to prove the superiority of their political systems and culture. Especially during Khrushchev's 'thaw’ period in the early 1960s, cultural 'soft power’ or cultural diplomacy became a significant Cold War 'weapon.' The US used cultural diplomacy more in the détente period of increased trade and cooperation with the Soviet Union. The journalists' exchanges were part of each side's cultural soft power. ASNE and the Soviet Union of Journalists arranged the visits in cooperation with the Soviet APN (Novosti Press Agency), established in 1961 to spread propaganda abroad, and the US Department of State, which promoted American interests abroad.

The theoretical framework acknowledging important distinctions between US and Soviet press systems is grounded in Fred S. Siebert, Theodore Peterson, and Wilbur Schramm's Four Theories of The Press. Their normative framework for global mass media systems reflects mass communication scholars' perceptions of simplified differences between open and closed societies in the 1960s. Positing that social and political structures influence press models, they identified four models authoritarian, libertarian, social responsibility, and Soviet-communist - that varied in accordance with social and political systems. ${ }^{25}$ The authoritarian press historically provided rulers with power to determine what information may be published. Under the libertarian theory, however, the press, free from government control, shared information with people that helped people understand truth and enhanced self-government. In the twentieth century, the social responsibility theory replaced the libertarian theory. The socially responsible press, free from government interference, adopted ethics codes and accepted the press's moral responsibility to monitor government, report on public affairs, and serve the public good. Under the Soviet-communist theory, the press served interests of the communist party and the Soviet state and shared revelations about the evils of capitalism and imperialism. 
During the Cold War, American journalists' freedom of information campaign contrasted political ideologies of liberal societies that enjoyed communications free from government control with ideologies of communist societies that published propaganda. ${ }^{26}$ American journalists associated press freedom with First Amendment theories and a right to know. ${ }^{27}$ They presumed people who expressed their views and received communication from others were capable of discovering truth and effectuating change without violence. Receiving true information was essential for people in a democratic society to make responsible decisions about their government and, thus, advance democracy. ${ }^{28}$ When advocating for better access to information, American journalists mentioned this vital role. ${ }^{29}$

US and Soviet journalists have 'incompatible' frames of reference for their press systems. American press freedom has meant the press operates as an institution independent from government interference or funding. Soviet journalists, on the other hand, have felt free from capitalist pressures they have associated with American media's dependence on advertising dollars. ${ }^{30}$ The US press has served readers by providing multiple points of view and information to help readers hold authorities accountable. The Soviet press provided communist party and state messages. The purpose of the Soviet media system, which the communist party owned, managed, and controlled, was to strengthen the power of the communist party elite and spread the socialist agenda. ${ }^{31}$ Censorship was an essential component in this system. ${ }^{32}$

The Soviet Constitution granted freedoms of speech and press exclusively for advancing socialism, and journalists had to serve the interests of socialism. Criticism of the socialist system or communist party was 'anti-Soviet activity’ punished under criminal law. ${ }^{33}$ The Soviet journalist doctrine even stated the communist party could demand ideological clarity from a journalist. ${ }^{34}$ Media scholar Epp Lauk wrote, 'the main function of Soviet media was to be an ideological weapon in the hands of the Party. ${ }^{35}$

Divergent media roles and professional standards must be taken into account when considering spheres of influence and which communication cultures might conflict. ${ }^{36}$ Sociocultural analysis can help to better understand the complexity of such divergent perspectives and experiences. ${ }^{37}$

\section{Spreading First Amendment values as transnational agents}

Conceptually, political historians have demonstrated how territories - shaped by underlying economic and political structures - can become global spaces where people construct and contest 
political borders. ${ }^{38}$ Cultural historians have proposed the paradigms histoire croiseée/ Verflechtungsgeschichte or transfert culturel/Kulturtransfer to understand how ideas and practices have influenced people and cultures across borders. ${ }^{39}$ Theorists Benedict Anderson and Alexis de Tocqueville argued that journalism and a lively public sphere are fundamental to how nations operate, thrive, and expand. ${ }^{40}$ Transnational histories of journalism have explored how ideas, concepts, norms, expertise, and content have been diffused across borders. ${ }^{41}$ Dutch journalism scholar Marcel Broersma has analysed the history of journalism through the paradigm of transnational contacts, patterns, and networks. Through a process he calls 'deterritorializing', journalists and their practices are subject to cross-border influences. ${ }^{42}$ Broersma has called for research on organisations that help spread journalism norms to reveal concrete examples of how ideas travel.

The present study illustrates what American editors learned during international exchanges and how these exchanges informed editors' freedom of information advocacy. 'By moving back and forth between the national and transnational level,' Broersma writes, 'journalism history emphasises the dialectic nature of these movements. ${ }^{43}$ Since the late 1930s, news organisations have been part of states' public diplomacy efforts. ${ }^{44}$ For instance, states have used international and transnational broadcasting to reach audiences' with a goal to propagandise. ${ }^{45}$ During the Cold War, Radio Free Europe and Radio Liberty were ‘broadcasting freedom' to people in Eastern Europe. ${ }^{46}$

The transnational perspective, according to American media historian Debra Reddin van Tuyll, 'recognizes that journalistic practices, techniques, technologies, personnel - even the transfer of ideas via journalistic products - are not and never have been constricted by national borders. ${ }^{47}$ Scholars also have conceptualised journalism history through 'entanglement', arguing that histories of media are interconnected with political, institutional, and cultural forces that transcend national boundaries. ${ }^{48}$ The histories of US-Soviet journalism overlapped, as each side sought insight into the other's society and press via exchanges.

\section{Method and primary sources}

This study uses qualitative historical research and textual analysis of original documents, including letters, hand-written diary entries, memoranda, news articles, and editorials. Primary sources were drawn from archival holdings and collections of seven ASNE members who participated in or organised exchanges. ${ }^{49}$ The authors also analysed Soviet journalists' writings, including letters and 
translations of articles published by Soviet journalists, who travelled to America, stored in US editors' files. ${ }^{50}$ A close historical review of primary and secondary sources informed the analysis. For triangulations, the authors accessed and interpreted ASNE Board draft meeting minutes and publications, including the ASNE Problems of Journalism, the Associated Press Managing Editors (APME) Red Book, and US Department of State records.

From a historical and political point of view, the 1960s are important because the period signals a second phase of American newsmakers' involvement in foreign policy and global discussions on media. Using ASNE members' records for analysis introduces potential limitations. US editors held American viewpoints of the press's role. At times US editors' portrayals of the American and Soviet press were overly idealised. Their documents, nevertheless, shed light on how they imagined their Soviet counterparts and their own advocacy for greater information flows. This analysis uses open coding of prevalent themes in documents. Together with deep historical contextualisation, close reading and analysis of discussions and events was instrumental in making cross-comparisons among primary sources. This study has sought to analyse American editors' advocacy for greater information flows by answering the research questions: a) How did archival records and articles of American editors who participated in or organised US-Soviet journalism exchanges describe people's rights and press rights? b) What values were ASNE members hoping to share with Soviet journalists? In analysing the discourse of American editors' ideas, plans, and experiences related to the exchanges, this study discusses the following major themes: a) encountering the 'Other', b) encouraging information flows, and c) differences in press systems.

\section{American Editors' views and advocacy for global press freedom}

Soviet journalists initially proposed Soviet-American journalist exchanges in 1959. ASNE members subsequently worked with the US Department of State and the Soviet Journalists' Union, which arranged for Soviet journalists to visit the United States in 1961 and 1970 and for American editors to visit the Soviet Union in 1962 and 1969. ${ }^{51}$ The Department of State identified two Soviet goals for the exchanges: receiving scientific and technical information and portraying the Soviet Union and Soviet policies positively. ${ }^{52}$ Long-term American goals were encouraging free flows of information between both countries, contributing to 'better mutual understanding,' and reducing international tension. Journalists from both countries also identified friendship and mutual understanding as goals for 
exchanges. ${ }^{53}$ The exchanges followed itineraries set by journalists in each country. ${ }^{54}$ Interactions between news organisation leaders and government officials were significant in part because the Cold War was waged on political, economic, and cultural fronts. ${ }^{55}$ Journalists involved in the exchanges also wrote articles detailing their travels, observations, and interactions.

The exchanges occurred at an important point in Cold War history. The early 1960s were marked by scares and political turning points. Nikita S. Khrushchev, chief of the Communist Party in the Soviet Union, and US President John F. Kennedy met in Vienna in June 1961 to discuss measures to ease Cold War tensions. Nonetheless, agitation continued to build. In August 1961 East Germany's Communist-led government started building a wall to block movement to west Berlin. Almost two months later Kennedy announced a naval blockade of Cuba, after the discovery of Soviet missiles that could be launched to destroy American cities. This short conflict, the Cuban Missile Crisis, brought the two powers to the brink of war before the Soviets agreed to remove the missiles. Kennedy appealed to American newspapers to self-censor important information; editors later lamented having done so. Agreeing to self-censorship hindered the American press's social responsibility to inform the public about the crisis. ${ }^{56}$

Even before this confrontation between Cold War superpowers, American editors had pleaded for better and more extensive coverage of both nations. 'Because there is a Cold War between our open society and the closed society of communism, I would say that good reporting must be both more responsible and more aggressive than ever,' stated Associated Press Managing Editors (APME) president J. Edward Murray, of the Arizona Republic, in 1961, two years after he first visited Russia. ${ }^{57}$ At the APME annual meeting, Murray demanded foreign news coverage be broader and of better quality: 'The people in our open society simply must read more foreign news and understand more of it. ${ }^{58}$ Murray, who had been a foreign correspondent in Europe, stated in a published APME report, 'In totalitarian Russia, only a few leaders and specialists have to keep up with news trends and new knowledge. In a democratic republic, a majority must be informed.' He presented the Russian press system as more authoritarian than the historically libertarian American press system. ${ }^{59}$

Despite significant differences between the American and Soviet press systems, journalists hoped exchanges could improve information flows and understanding between both nations. ${ }^{60}$ Vladimir Paramonov, Abroad magazine American Affairs editor, wrote, 'We had differences in appreciation, but the more we speak to each other, the more we see each other, the more we know each other, the more we make a contribution to that which is of the utmost importance, which is the cause of peace.' ${ }^{61}$ 


\section{Encountering the 'other'}

Editors' documents about US and Soviet journalism exchanges described social and cultural differences between both nations, including American wariness of communism and Soviet wariness of capitalism.

In 1961 eleven Soviet journalists, who visited the United States for almost three weeks, perceived divergent attitudes about Soviet people and communism. ${ }^{62}$ Two of those journalists noted American people primarily wanted friendly relations with Soviets. ${ }^{63}$ Victor V. Mayevsky, of Pravda, a newspaper organ of the communist party, wrote that President Kennedy said he was happy to see the delegation that visited the White House. 'We want to have good relations with the Soviet Union, whose peoples we hold in respect,' Kennedy said. ${ }^{64}$ Both countries' governments tried to impress foreign journalists on these exchanges. For instance, during their 1961 Washington D.C. visit, Soviet journalists stayed at the upscale Willard Hotel, steps from the political heart of the nation's capital. ${ }^{65}$ The president of the Board of the Novosti Press Agency and head of the visiting Soviet journalists delegation felt American people had great interest in learning about Soviet journalists, but he was not convinced American institutions were striving to promote international friendship or closer relations between both nations. ${ }^{66}$ During a visit to the US Capitol Building, he observed a sign for a bomb shelter beside an image of the US Constitution. The reporters were told, 'such signs are supposed to remind ordinary Americans about the danger of communism!'67 Later, he heard an American airport loudspeaker warn visitors 'of the approaching danger of communism, of the harmfulness of the "red" ideas.'

Suspicion of Soviet tendencies also were clear in papers of ASNE members who travelled to the Soviet Union. Paul Miller, president of The Gannett Newspapers and publisher of the Rochester TimesUnion and the Rochester Democrat and Chronicle, saved a Department of State publication that described the USSR as a closed society, 'secretive in the extreme. ${ }^{68} \mathrm{He}$ also kept a guide that indicated photographing military objects, hydro-electric installations, and radio stations was forbidden in the Soviet Union. ${ }^{69}$ Miller was advised against having any photos developed in the Soviet Union or having any papers he would not want authorities to see. ${ }^{70} \mathrm{He}$ also noted that in Moscow, a Russian journalist joked that an editor's hotel room would be bugged, but the person listening in would stop the recording if the American pretended Khrushchev's son-in-law, one of the journalists' guides, was in the room..$^{71}$ 
After traveling from the Soviet Union to Berlin in 1962, Miller and Walker Stone, editor in chief of the Scripps-Howard Newspapers, wrote a letter to Khrushchev. American newspapers published the letter challenging the Soviet head of state's assertions about what was best for Berlin. The editors explained their impressions of people living and working on both sides of the Berlin Wall. Germans disagreed with Khrushchev's statements that people would be 'much more at ease' if Western troops withdrew and a peace treaty were signed. 'Mr. Chairman, we hope you will be interested in the opinions of the people with whom we talked,' Miller and Walker wrote. 'In America, actions of governments are dictated by judgments of the people. ${ }^{72}$ The editors received praise for their 'hardhitting' letter. Roger H. Ferger, of The Cincinnati Enquirer, wrote that the letter showed Americans' 'attempts to get along with the Soviets, who are dedicated to our destruction.' The letter, which demonstrated American journalistic standards, convinced Ferger that Soviets were 'controlling the people under their domination. ${ }^{73}$

Significant events occurred in both nations before the next exchange trip for Soviet and American journalists. Almost five months before President Kennedy was shot in Dallas, he delivered his “Ich bin ein Berliner" speech. In 1963, the two superpowers agreed to ban tests of nuclear weapons above ground, underwater, and in space. They also established a direct telephone line between the White House and the Kremlin. After Khrushchev fell from power in 1964, and Leonid Brezhnev became the General Secretary, Americans questioned whether the Soviets would reverse Khrushchev's de-Stalinisation efforts.

American suspicions of Soviet tendencies were apparent again when ten American editors visited the Soviet Union for sixteen days in 1969. As had occurred in 1962, they were warned not to write until they had left the country because their belongings might be searched; and they were told their conversations would be monitored. ${ }^{74}$ One editor even proposed the travellers agree not to write while in the Soviet Union. ${ }^{75}$ Noting that Soviets would not do anything without a reason, Murray questioned in a speech draft why Soviets were inviting American editors to their country at that time. He suggested Soviets wanted to 'give us the line on China' and Soviets wanted to receive better press coverage than American correspondents had provided. ${ }^{76}$

Delegates from the 1969 trip wrote about contrasts between Americans' open society and Soviets' closed society. C.A. McKnight, of The Charlotte Observer, attempted to see the Soviet Union as Soviet people did, but 'a free man will never understand either their motivation or their resignation. ${ }^{77}$ Editors described Soviet people's suspicion of the United States and Soviet guides' tendencies to 
direct visitors to see the country's successes. ${ }^{78}$ In a draft letter The Miami News later published, the newspaper's editor Sylvan Meyer wrote that Americans wanted to see weaknesses as well as strengths to have a greater understanding of Soviet society. They wanted to learn about problems - not only progress. Meyer wrote that Soviets received distorted information with 'a heavy propaganda diet about the US government and its “imperialist” actions,' and Soviet and American people drew erroneous conclusions due to confusion, ideological differences, and suspicion. ${ }^{79}$

American delegates evaluated the Soviet Union according to pre-existing biases. Murray joined the 1969 trip because it 'had all the excitement and adventure of visiting the rival tribe. ${ }^{, 80} \mathrm{He}$ had visited a decade earlier and found the country fascinating. Editors were 'astonished and impressed' by what they saw as they travelled. ${ }^{81}$ Vincent Jones, executive director of the Gannett Newspapers, wrote that a simple description of specific aspects of Soviet culture made the country sound like paradise: all people have a place to live, medical care, and employment options. More than one hundred ethnic groups also lived harmoniously 'without America's tragic racial problem.' Yet, he described that country's living standards and productivity as below the rest of the Western World's with the country slowly emerging 'out of the Dark Ages' from the destruction of war. ${ }^{82}$

Having previously travelled to the Soviet Union, Murray, recognised the country had made great strides in science, industrialisation, and living standards during the $1960 \mathrm{~s} .{ }^{83}$ Jones, however, wrote that Soviet progress was accomplished 'through the most ruthless measures, and at the cost of freedoms we cherish. ${ }^{84}$

\section{Encouraging free flows of information to shape more accurate perceptions}

Americans participating in U.S. and Soviet exchanges between 1961 and 1970 argued greater flows of information could help their respective audiences develop more accurate perceptions of both nations. Soviet officials, however, had different conceptions of propaganda and truth than American journalists had.

Boris S. Burkov, 1961 delegation head and president of the Novosti Press Agency, wrote for the Soviet newspaper Izvestia that he sensed wariness from American journalists. Soviet journalists concluded that tensions arose because Americans lacked awareness of what Soviet peoples' lives were like in the Soviet Union. Burkov noted American people wanted truth about the USSR and they showed great interest in the Soviet journalists. The Soviet delegates, thus, questioned, 'Indeed, why is it that people in America know so little about the Soviet Union?’85 
American editors and government officials placed some blame for Americans' limited knowledge on restrictions the Soviet Union placed on foreign correspondents. Spending twenty-three days travelling through the Soviet Union in 1962, American journalists hoped to attain greater freedom for US correspondents in the USSR. Correspondents had limited access to Soviet places and people, which limited what Americans could learn about the country. Pierre Salinger, Kennedy's press secretary, wrote to ASNE members in 1962, 'we have to keep pushing steadily at the idea this situation must be opened up.' American people could not get a true picture of the Soviet Union until that country removed its restrictions on press coverage. ${ }^{86}$ Soviet people similarly could only receive limited information about Americans unless Soviet authorities gave Soviet journalists greater freedom to travel in the United States.

As thirteen ASNE members travelled to Moscow, Tashkent, Tbilisi, Volgograd, Leningrad, and Sochi in 1962, they tried persuading authorities to allow Soviet citizens to receive more American news. One American editor's news article indicated Khrushchev, the chairman of the Council of Ministers of the USSR, when meeting with American delegates, showed no desire to provide journalists greater freedom to travel in the USSR because the chairman wanted 'to keep an eye on them.' After denying an American's assertion that the Soviet press frequently distorted US actions and motives, Khrushchev indicated Soviet people neither wanted nor needed greater access to American news. 'His view is that what suits one country doesn't necessarily suit another,' Miller wrote. ${ }^{87}$ Americans' assertions that the Soviet press ought to provide both nations' perspectives to improve accuracy contradicted the Soviet press model. ${ }^{88}$

Differences in cultural expectations also emerged when Soviet journalists translated a transcript of the American editors' conference with Khrushchev. ASNE members assumed Soviet journalists might make some changes, but a newspaper clipping noted the US delegates were surprised their questions and comments were altered. When Khrushchev had asked whether the editors were restricted in any way in the Soviet Union, Lauren K. Soth, of the Des Moines Register and Tribune, answered 'yes.' Soth had requested to see more farms. That did not occur. The translation inaccurately indicated Soth responded 'no. ${ }^{89}$ Miller wrote in an article that the American delegates and newspapers outside the Soviet Union noted changes and omissions in the translated transcript. That upset Soviet journalists. Lee Hills, executive editor of the Knight Newspapers and ASNE president, told those journalists, 'Americans could not factually report the conference without also reporting significant, to them, changes and omissions. ${ }^{90}$ 
Americans stressed their conceptions of how to improve accuracy in news. 'We should like to get our story - fact, not fiction - before your people,' Felix R. McKnight, executive editor of the Dallas Times Herald, told a host on a train to Sochi. 'We shall tell our people the truth about what we have seen in the Soviet Union. All we ask is that the truth about us be presented to the people of your country. ${ }^{91}$ In a newspaper column, McKnight later described the country as 'a wasteland of suspicion' because Soviet people had not received the truth about the United States. Similarly, in an article, Miller wished Soviet journalists would 'give readers more facts. ${ }^{92}$ Soviet people received 'antiAmerican propaganda'; they were 'thoroughly propagandised to view us as greedy war profiteers unconcerned about peace and the rights of man,' McKnight wrote. ${ }^{93}$

ASNE members recognised in 1969 that people in both nations had received misinformation. An article draft Norman Isaacs sent William B. Dickinson, of the Philadelphia Bulletin, stated Soviets received propaganda about the United States 'being a nation of warmongers and racists', yet 'the average Russian seems to have read selectively and is surprisingly pro-American. ${ }^{94}$ Noting the American editors were insulated and restricted in where they could go in the USSR, a newspaper article by Jones stated editors received some misinformation and suspect statistics from Soviet officials. ${ }^{95}$ Placing some blame on Soviet suspicions of writers and restrictions on correspondents, Norman Isaacs, of the Courier Journal and Louisville Times, suggested something was 'sour' concerning US newspapers' limited coverage of the Soviet Union. Isaacs wrote in an unpublished article draft, as long as Soviet authorities restricted where journalists from both nations could go, neither country could expect accurate news about the other country. ${ }^{96}$

In an unpublished article draft, Murray argued the closed Soviet system showed only what Soviet leaders desired; in contrast, the open American system allowed journalists to see and write about problems and successes. Although conditions in the Soviet Union had improved over the decade since Murray's 1959 visit, he noted in an article draft that even the best things in that country did not reach top Western levels. 'Yet, all comparisons are misleading because this really is a different system, a different equation, which will be falsified if one compares only some of its factors with those of a different system.97

Despite significant differences between American and Soviet standards, two translated Soviet news clippings regarding the ASNE delegates' trip generally were positive. The Novosti Press Agency quoted Isaacs's explanation of Americans and Soviets' shared desires to achieve friendship and peace. ${ }^{98}$ A translated excerpt from Pravda, described two American editors as bourgeois, yet 
intelligent, sensible, and practical. Pravda noted those editors did not publish stories 'about the "iron curtain”, about “totalitarian government” and similar nonsense', although neither editor was suspected of having sympathy for communism. ${ }^{99}$

Although American editors' influence on Soviet people was limited, exchanges were considered useful for helping Americans learn about the Soviet Union and were hoped to 'influence that power in more constructive directions.' ${ }^{100}$ ASNE representatives promoted the ASNE International Committee's non-neutral goals of encouraging foreign journalists to visit the US, advocating for free flows of information between both countries, and protesting international censorship. ${ }^{101}$

\section{Grasping unbridgeable differences}

The US Department of State and ASNE intended the exchanges to foster greater information flows and understanding between people in both countries. ${ }^{102}$ Those goals related to Americans' valuing press freedom as independence from governmental controls and journalistic ideals to promote accuracy by providing multiple sides for each story. Soviet journalists, however, could only convey the truth of the Soviet Union and communist party. ${ }^{103}$

Contrasts between US and Soviet press organisations were apparent as journalists corresponded for months before the 1961 exchange. ASNE members showed frustration with how slowly they received updates from Moscow. In a letter, Lester Markel, foreign correspondent for The New York Times, suggested negotiations were slow because Khrushchev's son-in-law and editor of Izvestia, Alexei Adzhubei, had not decided whether to head the Soviet delegation. ${ }^{104}$ Markel called negotiations for the exchange 'unbelievable' and indicated he expected the exercise would be futile, but necessary to share where Americans stand 'in matters concerning the Iron Curtain.' ${ }^{105}$ Although Americans perceived Soviet media as a branch of their government and the US press as independent from the US government, Soviet officials and US government officials were involved in the exchanges. American and Soviet delegates' participation followed US State Department policies and goals for the exchanges.

Burkov, a member of the Soviet delegation that visited the United States in 1961, described advertising in American media. He likely perceived advertising as a capitalist influence on American media, as American journalists perceived the communist party as influencing Soviet media. He described radio news and commercial advertisements. An announcer spoke about racial disorder in Alabama, unemployment in the United States, and the upcoming Vienna summit between Kennedy and Khrushchev. Music and commercials separated each story. ${ }^{106}$ 
The Soviets involved in these exchanges had different perceptions of the press's role than American journalists had in the 1960s. Soviet editors for communist news outlets had to follow Soviet narratives, which they believed. A translation of Mayevsky's published explanation of his US visit stated he regretted some American journalists' preferences for neutrality. Mayevsky's 1961 Pravda article argued that a Soviet journalist's duty requires serving the USSR - not neutrality - 'especially when dealing with matters of the struggle for peace, for the future of mankind.' ${ }^{107}$

After the first exchanges, an annual ASNE International Committee report addressed differences between communist nationals' perceptions of press freedom and Americans' perceptions of press freedom. ASNE did not take a neutral stance on government control of press content. Indeed, the committee recommended the organisation add its voice of protest to discourage censorship around the world. ${ }^{108}$ This stance followed 1960 ASNE president James Russell Wiggins's assertion people needed a Fourth Estate, 'so powerful and so responsible that none of the massive agglomerations of collective power can intimidate its search for the truth. ${ }^{109}$ ASNE members were especially concerned about government control over information in the Soviet Union after writers were sent to labour camps or expelled for writing or exporting messages that did not toe the Soviet line. ${ }^{110}$

Ideal roles for criticism and dissent varied between Soviet-communist and social responsibility press models. In a newspaper article, Meyer wrote that journalists accepting rather than openly challenging Soviet narratives was the greatest difference in their national philosophies. ${ }^{111}$ When Murray asked to see a writer sent to a labour camp in 1966 after smuggling writings abroad, the American editors were not amused by the response from Andrei Itskov, executive secretary of the foreign section of the Soviet Union of Journalists. 'All you have to do is violate some of our more serious laws, and you'll be sure to get to see him,' Itskov said, then laughed. ${ }^{112}$ Americans also made little ground when attempting to discuss the 1968 uprising in Czechoslovakia. In an article Dickinson described receiving comments that came almost directly from a Pravda editorial about 'anti-socialist' forces encouraged by 'imperialism’ attempting to tear away Czechoslovakia. ${ }^{113}$ Dickinson wrote in an unpublished article draft that Russian journalists 'were not newsmen in our sense of the word but rather public relations men.'114

Soviet journalists saw their government as their publisher, thus 'Dissenters are oddballs, whether literary types or journalists,' Meyer wrote. ${ }^{115}$ Soviet journalists, however, indicated their publications did provide some critical content. An unsigned editorial in Dickinson's papers stated the Soviet press's watchdog role was surveying 'the cultural scene in harsh terms. ${ }^{116}$ Editorials and letters 
to the editor could focus on housing, land use, transportation infrastructure, or personal economics. Papers received thousands of letters, many written anonymously. The letters did 'not attack officials or question the merit of Soviet socialism.' Although publications sent copies of letters to Soviet government officials, Americans indicated Soviet journalists primarily addressed lack of newsprint as a limitation on their newspapers. ${ }^{117}$

The Soviet media operated under censorship to prevent the press from undermining the communist party or socialist ideology. ${ }^{118}$ In 1962, a published newspaper article by Michael J. Ogden, of The Providence Journal, described the Soviet press 'as an arm of the government and as a propaganda force. ${ }^{119}$ In a speech draft, Murray similarly wrote, “The Russian correspondent must write only the official party line, that is only propaganda." ${ }^{120}$ Supporting Ogden and Murray's perceptions of Soviet press responsibilities to infuse public opinion with a party line, Dickinson noted editors heard the same message across the land they heard from Izvestia bosses. 'On foreign policy, Soviet leaders speak with one voice,' Dickinson wrote in an article draft sent to the North American Newspaper Association. ${ }^{121}$

Journalists in each country held different conceptions of how to report truth. Dickinson wrote Soviet journalists criticised American foreign correspondents for reporting information from the Kremlin when correspondents were not there. ${ }^{122}$ During an interview with the Izvestia editorial board, an Izvestia editor accused American media of misleading readers by printing the false Pekingside of stories about tensions between China and the Soviet Union. The Soviet editor said journalistic responsibility required running the 'true story. ${ }^{123}$ Americans countered that as long as neither country allowed US correspondents to visit the border, correspondents could only convey what each country reported. Soviets responded that Americans should report the truth, the Soviet side. ${ }^{124}$

High-ranking Soviet journalists' communist party loyalties provided benefits US journalists lacked. One Soviet journalist flashed a card whenever American delegates encountered challenges in the USSR. Showing the card convinced an officer not to ticket a speeding driver. The head of the International Department of the Ukrainian Union of Journalists also sprung the American delegation's photographer 'when he fell into the clutches of the police for snapping intimate shots of soldiers.' ${ }^{125}$ The American news executives did not have political clout or responsibilities comparable to those of communist news officials who participated in the exchanges. 
Whereas American editors strove to serve the people's right to know under the social responsibility model, Soviet journalists served Soviet interests. ${ }^{126}$

\section{Building bridges of understanding}

The cultural Cold War in the 1960s extended to how American and Soviet audiences perceived each other, whether foreign correspondents could access news in each country, and what narratives media published. The journalists' exchanges took place during a time of mutual suspicion and political tension. After the Soviet Union of Journalists initiated the exchanges in 1959, Americans conveyed the trips as beneficial for portraying East-West realities and attitudes. ${ }^{127}$ US editors' records reveal significant insights into transnational activities and attempts to spread Western journalistic ideals during this period.

Scholarship on transnational journalism has emphasised the need to study the interchanges of ideas and transfer of journalistic notions, including conventions and routines. ${ }^{128}$ This study contributes to press historians' understanding of the Cold War period by explaining transnational experiences of free press advocates who engaged in exchange trips with Soviet journalists, advocated for free flows of information, and wrote about their experiences.

During a period when government-press tensions grew through the US involvement in Vietnam and South East Asia, US civil rights struggles, and increasing public scepticism, archival records show journalists from both nations made significant efforts to communicate with each other. Participants in these exchanges gained insights into foreign societies and their messaging. The delegates' exchanges of ideas and meetings were significant. Through their observations, interactions and writings, American editors tried to build bridges between journalists from both nations as well as build bridges of cultural understanding between journalists and their audience. ${ }^{129}$

American editors hoped to share their journalism values, increase American correspondents' access to Soviet information, and encourage free flows of information between the United States and Soviet Union to increase understanding between both nations. Cultural differences prevented Americans from convincing Soviets to adopt Western journalism values or to increase American correspondents' access to Soviet information. Allowing free flows of information would have run counter to the ideals for the Soviet media system, in which news and books were censored. Americans did, however, contribute to ASNE and Department of State and ASNE goals to increase understanding 
through journalists' travels and stories about their travels. Still, Americans' records reflected their preferences for American values and cast Soviet people and journalists as 'others' in a closed society. ${ }^{130}$

These documents shed light on the American press's role as a soft power, particularly as ASNE members informed Soviet journalists about American values for press freedom. Gathering and reporting information fell within the parallel structure, ASNE and the Department of State goals. Although these exchanges did little to lift the political Iron Curtain, they allowed members of the press and audiences to see and better grasp differences between open and closed societies. As the findings of this study indicate, American editors hoped to advocate for transnational appreciation for free flows of information. American editors learned, however, it was 'next to impossible' to explain Western notions of press freedom in a manner that could satisfy journalists from Communist or neutral nations. ${ }^{131}$

Records regarding the exchanges shed light on significant differences in American and Soviet perceptions of the press's role in informing audiences about political and global affairs. Editors from both nations had divergent concepts of truth. ASNE members' records show there was mutual cynicism, yet genuine desire to learn about life 'on the other side.' Their original stories, on-theground reports and interviews with Soviet officials transcended images and narratives perpetuated by American illusions and nationalistic propaganda, as the editors attempted to increase mutual understanding. ${ }^{132}$

Extensive analysis of archival sources has indicated that American editors contrasted their freedoms with Soviet controls. Editors described their advocacy for American and Soviet correspondents to receive greater access to information, places, and people, and they had some success in improving understanding through their exchanges. These findings add to the body of scholarship on editors' campaigns for freedom of information, domestically and internationally, after World War II. ${ }^{133}$ Future research should explore Soviet archival records to learn more about Soviet goals for these exchanges, perceptions of these exchanges, and perceptions of the Americans' advocacy for free flows of information.

\section{Notes}

1. Margaret A. Blanchard, Exporting the First Amendment: The Press-Government Crusade of 1945-1952 (New York: Longman, 1986). 
2. Margaret A Blanchard, Revolutionary Sparks: Freedom of Expression in Modern America (New York: Oxford University Press, 1992).

3. Ibid.

4. Arthur C. Deck Papers, Box 7, Folder 1, in J. Willard Marriott Library, University of Utah Manuscripts Division, ASNE Board of Directors meeting minutes from April 14, 1969 stated American journalists visited the USSR in 1969 and Soviet journalists visited the US in 1970. This study does not extensively address Soviet journalists' travels due to the focus on American editors' perceptions and due to limited records reflecting Soviet journalists' perspectives.

5. Wiggins Papers, Box 43, Folder 21, Letter to D.D. Kraminov from Lester Markel, June 9, 1960.

6. Fred S. Siebert, Theodore Peterson, and Wilbur Schramm. Four Theories of the Press: The Authoritarian, Libertarian, Social Responsibility, and Soviet Communist Concepts of What the Press Should Be and Do (Champaign: University of Illinois Press, 1956).

7. Margaret A. Blanchard, "The Crusade for Worldwide Freedom of Information: American Attempts to Shape World War II Peace Treaties," Journalism Quarterly 60, no. 4 (1983): 583.

8. See, for example: Marcel Broersma, “Transnational Journalism History: Balancing Global Universals and National Peculiarities," Medien \& Zeit 25, no. 4 (2010): 10-15; Marcel Broersma, Form and Style in Journalism: European Newspapers and the Presentation of News, 1880-2005 (Leuven: Peeters, 2007); Kevin Grieves, Journalism across Boundaries: The Promises and Challenges of Transnational Journalism (New York: Palgrave, 2012).

9. Blanchard, Revolutionary Sparks; Blanchard, “The Crusade”; Emily Erickson, “The Watchdog Joins the Fray: The Press, Records Audits, and State Access Reform," Journalism \& Communication Monographs 16, no. 2 (2014): 104-154; Shannon E. Martin, Freedom of Information: The News the Media Use (New York: Peter Lang, 2008); Shannon E. Martin and Kamilla Benko, "Forming FOIA: The Influence of Editors and Publishers on the Freedom of Information Act," Media History Monographs 14, no. 1 (2012): 1-33.

10. Blanchard, Revolutionary Sparks.

11. Michael Schudson, The Rise of the Right to Know: Politics and the Culture of Transparency, 1945-1975. (Cambridge: Harvard University Press, 2015).

12. Martin E. Halstuk and Bill F. Chamberlin, “The Freedom of Information Act 1966-2006: A Retrospective on the Rise of Privacy Protection over the Public Interest in Knowing what the Government's up to," Communication Law and Policy 11, no. 4 (2006): 511-564. 
13. Timothy E. Cook, Governing With the News: The News Media as a Political Institution (Chicago: University of Chicago Press, 1998).

14. Erin Coyle, Elisabeth Fondren, and Joby Richard, "Advocacy, Editorial Opinion, and Agenda Building: How Publicity Friends Fought for Louis D. Brandeis’s 1916 Supreme Court Confirmation,” American Journalism 37, no. 2 (2020): 165-190; Erin Coyle, “The Moral Duty of Publicity: Louis Dembitz Brandeis’ Crusades for Reform in the Press and Public Affairs, 1890-1916,” Journalism History 35, no. 3 (2009): 162-167.

15. Michael Schudson, “The Sociology of News Production," Media, Culture and Society 11, no. 3 (1989): 263-282; and Michael Schudson, "Fourteen or Fifteen Generations: News as a Cultural Form and Journalism as a Historical Formulation," American Journalism 30, no. 1 (2013): 29-35.

16. Erin Coyle, “Press Freedom and Citizens' Right to Know in the 1960s: Sam Ragan's Crusades to Provide the Public with Access to Criminal Justice Information,” Journalism History 41, no. 1 (2019): 44-45.

17. Erickson, “The Watchdog," 119.

18. Kiyul Uhm, “The Cold War Communication Crisis: The Right to Know Movement," Journalism \& Mass Communication Quarterly 82, no.1 (Spring 2005): 132.

19. Schudson, The Rise.

20. Ronald T. Farrar, Mass Media and the National Experience, Essays in Communications History (New York: Harper \& Row, 1971), 13.

21. George Seldes, The People Don't Know: The American Press and the Cold War (New York: Gaer Associates, 1949), 1.

22. Ibid., 2.

23. Andreas Killen and Stefan Andriopoulos, “Editor’s Introduction on Brainwashing: Mind Control, Media, and Warfare," Grey Room 45, (Fall 2011): 6-17.

24. Martin and Benko, "Forming FOIA," also see: Marion C. Wrenn, "Making the World Safe for 'Autonomy'? The US Initiative to Reorient ‘Foreign Journalists,' 1945-1970” in Journalism Education, Training and Employment, ed. Bob Franklin and Donica Mensing (New York: Routledge, 2011), 83-96.

25. Siebert et al., Four Theories, 40, 105, 145.

26. Schudson, The Rise.

27. Coyle, "Press Freedom": 46.

28. Thomas I. Emerson, "Legal Foundations of the Right to Know," Washington University Law Quarterly 1976, no. 1 (January 1976): 2. 
29. James R. Wiggins, Freedom Or Secrecy: On the Freedom of the Press (New York: Oxford University Press, 1956), 24; Erickson, “The Watchdog”; Potter Stewart, “Or of the Press,” Hastings Law Journal 26 (1974): 631.

30. Siebert et al., Four Theories, 105.

31. Paul Lendvai, The Bureaucracy of Truth: How Communist Governments Manage the News (Boulder, CO: Westview Press, 1981).

32. See: Epp Lauk, "Practice of Soviet Censorship in the Press. The Case of Estonia." Nordicom Review 20, no. 2 (1999): 27-39; Lioudmila Savinitch, "Pragmatic Goals and Communicative Strategies in Journalistic Discourse Under Censorship," in Power Without Domination: Dialogism and the Empowering Property of Communication, ed. Eric Grillo. (Amsterdam: John Benjamins Publishing Company, 2005): 107-138.

33. See: Epp Lauk, Petr Šámal, and Teodora Shek Brnardić, “The Protean Nature of Communist Censorship: The Testimony of Collections," in Handbook of COURAGE: Cultural Opposition and Its Heritage in Eastern Europe, ed. Balázs Apor, Péter Apor and Sándor Horváth (2019), available: http://cultural-opposition.eu/ activities/handbook/).

34. Jaromír Volek and Marína Urbániková, "Predictors of Mistrust: Towards Basic Characteristics of Czech Mistrusting News Media Audiences," Observatorio (OBS*) 12, no. 1 (2018): 01-18.

35. Epp Lauk, “Estonian Journalists in Search of New Professional Identity,” Javnost-The Public 3, no. 4 (1996): 95; see also: Peeter Vihalemm and Marju Lauristin, "Political Control and Ideological Canonisation. The Estonian Press during the Soviet Period," in Vom Instrument der Partei zur Vierten Gewalt: die ostmitteleuropäische Presse als zeithistorische Quelle, ed. Mühle, Eduard (Marburg: Verlag Herder-Institut, 1997): 103-109.

36. James Carey, "A Cultural Approach to Communication," Reprinted in Reader in Mass Communication Theory, ed. D. McQuail (London: Sage, 2002), 36-45.

37. J. V. Wertsch, Mind as Action (New York: Oxford University Press. 1998).

38. Charles S. Maier, Once Within Borders: Territories of Power, Wealth, and Belonging since 1500 (Cambridge: Harvard University Press, 2016); see also: Benedict Anderson, Imagined Communities: Reflections on the Origin and Spread of Nationalism (London: Verso Books, 1983).

39. Michael Werner and Bénédicte Zimmermann, "Vergleich, Transfer, Verflechtung. Der Ansatz der Histoire croisée und die Herausforderung des Transnationalen," Geschichte und Gesellschaft 28, no. H. 4 (2002): 607-636.

40. Anderson, Imagined Communities, 37. 
41. See, for example: Broersma, "Transnational Journalism”; Broersma, Form and Style; and Grieves, Journalism across Boundaries.

42. Broersma, “Transnational Journalism," 10.

43. Ibid., 12 .

44. Philip Seib, “Transnational Journalism, Public Diplomacy, and Virtual States,” Journalism Studies 11, no. 5 (2010): 734-744.

45. Philip Seib, Broadcasts from the Blitz: How Edward R. Murrow Helped Lead America into War, (Dulles, VA: Potomac, 2006), 747.

46. Arch Puddington, Broadcasting Freedom: The Cold War Triumph of Radio Free Europe and Radio Liberty. (Lexington: University Press of Kentucky, 2000).

47. Debra Reddin van Tuyll, "Journalism History without Borders: The Transnational Paradigm and the Case of John Mitchel," American Journalism 34, no. 1 (2017): 91-102.

48. Marie Cronqvist and Christoph Hilgert, "Entangled Media Histories: The Value of Transnational and Transmedial Approaches in Media Historiography,” Media History 23, no. 1 (2017): 130-141.

49. Deck Papers; William B. Dickinson Papers, University of Wyoming American Heritage Center; C. A. McKnight Papers, J. Atkins Murray Library, University of North Carolina, Charlotte; Paul Miller Papers, Oklahoma State University Archives; Walker Stone Papers, Wisconsin State Historical Society Archives; James Russell Wiggins, Raymond H. Fogler Library, University of Maine at Orono; Sylvan Meyer Papers, Southern Historical Collection, The Wilson Library, University of North Carolina at Chapel Hill.

50. Wiggins Papers, Box 43, Folder 21, Letter to James Russell Wiggins from N. Dayakonov, dated June 23, 1961. The letter accompanied translations of published articles Soviet journalists wrote about their 1961 US trip.

51. See, for example: Miller Papers, "Miller to Tour Russia with Group of Editors," Rochester Times-Union, June $18,1962$.

52. Miller Papers, "A Report on the United States Exchanges Program with the Soviet Union and Eastern Europe,” US Department of State, April 15, 1962.

53. Miller Papers, Letter from Vladimir Paramonov, American Affairs editor of the magazine "Abroad" to Paul Miller, n.d. Dickinson Papers, Box 11, Folder 2, 25 August 1969 diary entry. 
54. For example, see: "Report of the 1963-1964 [International] Committee Report to Board of Directors," Problems of Journalism (Washington DC: ASNE, 1964), 234-235. ASNE members had a goal to repeat such exchanges after five to eight years.

55. See: Laura A. Belmonte, Selling the American Way: US Propaganda and the Cold War (Philadelphia: University of Pennsylvania Press, 2013).

56. J. Edward Murray speech, “National Purpose,” APME Red Book 1961, 13.

57. APME Red Book 1961, 7.

58. Ibid., 9.

59. Murray, "National Purpose," 14.

60. Miller Papers, "A Report.”

61. Miller Papers, Letter from Vladimir Paramonov to Paul Miller, n.d.

62. Wiggins Papers, Box 43, Folder 21, Trans. articles and letter to James Russell Wiggins from N. Dayakonov, dated June 23, 1961.

63. Wiggins Papers, Box 43, Folder 21, Trans. Mayevsky, "Washington and Vienna," Pravda, May 25, 1961, and Wiggins Papers, Box 43, Folder 21, Trans. Boris S. Burkov, "Soviet Newsmen in America," Izvestia, May 27, 1961.

64. Wiggins Papers, Box 43, Folder 21, Trans. Mayevsky, “Washington.”

65. Wiggins Papers, Box 43, Folder 21, “Soviet Union Exchange of Delegates, 1959-1962.”

66. Wiggins Papers, Box 43, Folder 21, Trans. Burkov, "Soviet Newsmen."

67. Ibid.

68. Miller Papers, “A Report.”

69. Miller Papers, Jennifer and Victor Louis, “Everyday Information for Visitors to Russia,” Darton \& Co., 1960.

70. Stone Papers, Box 11, June 6, 1962 Letter to Paul Miller from Relman Morin; Miller Papers, June 13, 1962 Letter to Paul Miller from Ham Allen.

71. Miller Papers, “Red Security” in Russia: 1962, 20.

72. Miller Papers, Paul Miller and Walker Stone, “The Open Letter to Khrushchev” in Russia: 1962, 43.

73. Stone Papers, Box 11, July 27, 1962 Letter to Walker Stone from Roger H. Ferger.

74. McKnight Papers, Box 5, Folder 12, C.A. McKnight, "Misgivings Were Due to Myths," Charlotte Observer, n.d.

75. Deck Papers, Box 2, Folder 7, July 1, 1969 Letter to Paul Ringler from Norman E. Isaacs. 
76. Murray Papers, Box 3, J. Edward Murray, speech draft, “Ten U.S. Editors in the Soviet Union," delivered to the Phoenix, Arizona, downtown Rotary Club, October 3, 1969.

77. McKnight Papers, Box 5, Folder 12, C.A. McKnight, “Contrasts Became Evident at Once,” Charlotte Observer, n.d.

78. McKnight Papers, Box 5, Folder 12, C.A. McKnight, “China Upsets Soviets More than Vietnam,” Charlotte Observer, n.d.; Meyer Papers, Clipping of “Open Letter to a Soviet Friend,” October 9, 1969.

79. Meyer Papers, Box 8, Folder 75, Meyer, Draft of “Open Letter to a Soviet Friend,” n.d.

80. Murray Papers, Box 3, speech draft, "Ten U.S. Editors.”

81. Dickinson Papers, Box 11, Folder 2, Norman Isaacs, draft article, n.d.

82. Dickinson Papers, Box 11, Folder 5, Vincent Jones, Russia, 1969, 1.

83. Dickinson Papers, Box 11, Folder 5, J. Edward Murray, Russia Revisited, (Phoenix: The Arizona Republic, 1969), 22. Murray wrote, 'By our standards, the Soviet system leaves much to be desired. But I think it makes progress ...'

84. Dickinson Papers, Box 11, Folder 5, Vincent Jones, Russia, 1969, 1.

85. Wiggins Papers, Box 43, Folder 21, Transl. Burkov, "Soviet Newsmen.”

86. Miller Papers, Letter dated June 12, 1962.

87. Miller Papers, Miller, “2 1/2 Hours with Mr. K.” in Russia: 1962, 8-9.

88. See for example: Epp Lauk and Tiiu Kreegipuu, "Was It All Propaganda? Journalistic Practices of 'Silent Resistence' in Soviet Estonian Journalism,” Acta Historica Tallinnensia 15, no. 1 (2010): 167-169.

89. Associated Press, “Transcript Convinces Newsmen 'Da' Can Mean 'Nyet' in Russia,” Chattanooga Daily Times, July 17, 1962, 4 .

90. Miller Papers, Miller, “Transcript Hass” in Russia: 1962, 11-12.

91. Miller Papers, Miller, “The Great Georgians” in Russia: 1962, 16.

92. Miller Papers, Miller, “Anti-U.S. Propaganda” in Russia: 1962, 7.

93. Felix R. McKnight, “Impressions of Nikita Khrushchev,” Corsicana Daily Sun, August 13, 1662, 18.

94. Dickinson Papers, Box 11, Folder 2, Norman Isaacs, draft article, n.d.

95. Dickinson Papers, Box 11, Folder 5, Vincent Jones, Russia, 1969, 3.

96. Dickinson Papers, Box 11, Folder 2, Norman Isaacs, draft article, n.d.

97. Dickinson Papers, Box 11, Folder 4, J. Edward Murray, draft article, n.d.

98. Dickinson Papers, Box 11, Folder 2, Trans. "American Editors in Leningrad," Novosti Press Agency. n.d. 
99. Deck Papers, Trans. excerpt attributed to Pravda, December 29, 1969.

100. Miller Papers, “A Report.”

101. "Report of the 1963-1964”), 234-235.

102. Jones wrote, 'We urged repeatedly that their restrictions on reporting by American correspondents in Russia be lifted and that they send more people to see the United States.' Dickinson Papers, Box 11, Folder 5, Jones, Russia, 1962, 4.

103. Lauk and Kreegipuu, “Was It All?”: 167-168.

104. Wiggins Papers, Box 43, Folder 21, Lester Markel to James Russell Wiggins, March 7, 1961.

105. Ibid.

106. Wiggins Papers, Box 43, Folder 21, Trans. Burkov, "Soviet Newsmen."

107. Wiggins Papers, Box 43, Folder 21, Trans. Mayevsky, "Washington.”

108. For example, see: "Report of the 1963-1964 International Committee Report to Board of Directors," Problems of Journalism (Washington DC: ASNE, 1964).

109. J. R. Wiggins, “The Power and Responsibility of the Press,” Journalism Quarterly 37, no. 1 (1960): 40.

110. For example, Murray wrote about Anatole Shub, of the Washington Post, being expelled after indicating there were thousands of Soviet political prisoners. Dickinson Papers, Box 11, Folder 5, Murray, Russia Revisited, 12.

111. Meyer Papers, Box 8, Folder 75, clipping of “Soviets Touchy about Czechs, China, Viet.,” n.d.

112. Dickinson Papers, Box 11, Folder 4, William Dickinson, draft article for ASNE Bulletin, n.d.

113. Dickinson Papers, Box 11, Folder 2, US-USSR Relations, n.d.

114. Dickinson Papers, Box 11, Folder 2, unpublished draft article, n.d.

115. Meyer Papers, Box 8, Folder 75, clipping of “Soviets Touchy.”

116. Folder 2 in Box 5 of Dickinson's papers includes a copy of an unsigned October 5, 1969, op-ed.

117. Dickinson Papers, Box 11, Folder 5, J. Edward Murray, Russia Revisited, 18. Murray wrote that the criticism is a tame, domesticated criticism aimed at the way policies are being executed, usually by nameless underlings.'

118. Lauk and Kreegipuu, “Was It All?”: 167-168.

119. Michael J. Ogden, “Red Press Shapes Russian Minds,” Bennington Banner, 12 September 1962.

120. Murray Papers, Box 3, Draft of a May 9, 1963 speech, “Foreign Reporting of the U.S.”

121. Dickinson Papers, Box 11, Folder 4, Dickinson, “A Russian Journey--V,” sent to the North American Newspaper Association for release October 25, 1969.

122. Dickinson Papers, Box 11, Folder 2. Dickinson, Draft of “Eleventh Instalment," n.d. 
123. Dickinson Papers, Box 11, Folder 2, US-USSR Relations, n.d.

124. Ibid.

125. For example, see: Dickinson Papers, Box 11, Folder 5, Jones, Russia, 10.

126. See, for example: Lauk and Kreegipuu, "Was It All?”

127. Wiggins Papers, Box 43, Folder 21, Memorandum for the Board Meeting, October 15, 1959.

128. Broersma, “Transnational Journalism,” 10; van Tuyll, “Journalism History,” 93.

129. Paul Miller's papers include letters from a reader, Casper Solomon, who wrote to Paul Miller on August 7, 1962, that Miller's articles on Russia 'have been revealing as well as refreshing, and it [sic.] gives your readers an accurate picture of inside Russia.'

130. For example, see: Murray Papers, Box 3, Murray’s draft speech, “Ten U.S. Editors” stated the USSR is a closed society with no political freedom.

131. ASNE 1963-1964 International Committee Report.

132. For example, Miller Papers, In an August 6, 1962 letter to Paul Miller, US Congress member Alexander Pirnie praised Miller's reports on the editors' tour. Pirnie wrote 'They have been most informative and should dispell [sic.] many illusions as to the Soviet Regime.'

133. Blanchard, Revolutionary Sparks; Blanchard, "The Crusade”; Erickson, “The Watchdog," and Martin, Freedom.

\section{Biographies}

Erin Coyle is an associate professor of journalism at Temple University in Philadelphia, Pennsylvania. She received a Ph.D. in Mass Communication from the University of North Carolina at Chapel Hill in 2010. She holds an M.S. in Journalism from Ohio University and a B.A. in English and Journalism from Emory University. Her research focuses on journalism history and law, freedom of information, advocacy by journalists, and privacy rights. Coyle received an American Heritage Center Travel Grant to support this research.

Elisabeth Fondren is an assistant professor of journalism at St. John's University in New York. She received a Ph.D. in Media \& Public Affairs from Louisiana State University (Manship School of Mass Communication) in 2018. She holds an M.A. in International Journalism from City, University of London and a B.A. in English and German Philology, Literature and Cultural History from Heidelberg University. Her research explores the history of international journalism, government propaganda, military and media relations, and freedom of speech during wartime. 


\section{TMG Journal for Media History}

Volume 24 No $(1 / 2) / 2021$

DOI

https://dx.doi.org/10.18146/tmg.785

\section{PUBLISHER}

Netherlands Institute for Sound and Vision

\section{COPYRIGHT}

Each article is copyrighted (c) by its author(s) and is published under license from the author(s). When a paper is accepted for publication, authors will be requested to agree with the Creative Commons Attribution 4.0 International License. 